\title{
IAMJ
}

INTERNATIONAL AYURVEDIC MEDICAL JOURNAL

\section{CLINICAL EVALUATION OF THE EFFICACY OF LEKHANBASTI AND MEDOHARAVIDANGADILAUHA IN THE MANAGEMENT OF DYSLIPIDEMIA}

\section{$\underline{\text { Noor Sayeda Shabnam Ahmed }}^{1}, \underline{\text { Om Prakash Gupta }}{ }^{2}, \underline{\text { Bishnu Prasad Sarma }}^{3}$}

${ }^{1}$ PG Scholar, Dept. Of Kayachikitsa, Govt Ayurvedic College \& Hospital Guwahati, Assam, India

${ }^{2}$ Professor \& Ex- HOD, Kaya Chikitsa Dept. Govt. Ayurvedic College \&Hospital, Guwahati, Assam, India

${ }^{3}$ Ex-Principal, Consultant \& Professor, Dept of Kayachikitsa, Govt. Ayurvedic College \& Hospital, Guwahati, Assam, India

Corresponding Author: shabs3764@gmail.com

\section{https://doi.org/10.46607/iamj0709072021}

(Published Online: July 2021)

Open Access

(C) International Ayurvedic Medical Journal, India 2021

Article Received: 23/06//2021 - Peer Reviewed: 24/06/2021 - Accepted for Publication: 25/06/2021

\section{Check for updates}

\section{ABSTRACT}

This study was conducted to evaluate the efficacy of lekhanbasti and medoharavidangadilauha in the management of dyslipidemia. Consent from all the selected patients was taken before the study after explaining to them about the disease and the procedure. Ethical clearance was accredited by the ethical committee of Government Ayurvedic College and Hospital Guwahati, Assam. Patients from IPD and OPD of the department of Kayachikitsa of the aforesaid institute were chosen. Lekhanbasti niruha and tiltaila anuvasana on alternate days was administered for 8 days Follow up was done at an interval of 30,60 and 90 days. Oral intake of medoharavidangadilauha was advised during these 90 days. The basti was repeated in the follow-up period. After comparing the fasting lipid profile before and after treatment it was found that there was a significant change in it.

Keywords: Dyslipidemia, Lekhanbasti, Medoharavidangadilauha, Medoroga, Fasting lipid profile.

\section{INTRODUCTION}

Dyslipidemia is a bane of today's modern age. Lipids are a very essential component of our body but any disorder in them results in complications. Dyslipidaemia is a key contributor to atherosclerosis, coronary artery disease (CAD) and peripheral vascular diseases (PVD. Unwholesome dietary habits, increasing mental stress, abstinence from physical exercise, certain medications like oral contraceptives 
are the cause of Dyslipidemia to mention a few. Though there is no direct mention of Dyslipidemia in Ayurvedic classics from the etiopathogenesis it can be correlated to Medoroga. Excessive accumulation of medas at various parts of the body is termed in Ayurveda as Medoroga. Sleshmavriddhikara aharasevana and genetic factors i.e. beejaswabava are the main causative factors of medaroga (dyslipidemia). Since kaphadosha and medadhatu are mutually dependent, any etiological factors (nidana) which increase kaphadosha will increase meda fat (medavriddhi) thereby resulting in dyslipidemia.

\section{MATERIALS AND METHOD}

The clinical study was done on 30 patients. They were explained about their disorder and the procedure of treatment. The consent form was taken before the study. The ethical clearance was given by the Institutional Ethical Committee of Government Ayurvedic College and Hospital Guwahati, Assam (ref no-IEC/19, 20-213). Patients from IPD and OPD of Kayachikitsha department of the above-mentioned institute were taken for the study. Katutailaabhyanga and nadiswedan followed by lekhanbastiniruha and tiltailaanuvasana on alternate days for a period of 8 days $^{2}$ were given in addition to this medoharavidangadi lauha ${ }^{8,4}$ orally was also advised for 90 days. Follow up was done at an interval of 30, 60 and 90 days. The basti procedure was repeated at each follow.

Table 1: Content of lekhanbasti

\begin{tabular}{|l|l|}
\hline Drug & Quantity \\
\hline Triphala decoction & $300 \mathrm{ml}$ \\
\hline Gomutra & $200 \mathrm{ml}$ \\
\hline Honey & $50 \mathrm{ml}$ \\
\hline Til oil & $60 \mathrm{ml}$ \\
\hline Saindhavalavana & $10 \mathrm{gm}$ \\
\hline Suddhashilajatu & $500 \mathrm{mg}$ \\
\hline Yavakhsar & $5 \mathrm{gm}$ \\
\hline Hingu & $125 \mathrm{mg}$ \\
\hline
\end{tabular}

Table 2: days of Administration

\begin{tabular}{|l|l|}
\hline Day & Type $^{\text {of Basti }} \mathbf{2}^{\mathbf{2}}$ \\
\hline 1 & Anuvasana \\
\hline 2 & Niruha \\
\hline 3 & Anuvasana \\
\hline 4 & Niruha \\
\hline 5 & Anuvasana \\
\hline 6 & Niruha \\
\hline 7 & Anuvasana \\
\hline 8 & Anuvasana \\
\hline
\end{tabular}

\section{SELECTION CRITERIA:}

\section{A. Inclusion Criteria:}

1. Patients between age group (20 -70) years of either sex.

2. Patients having at least one of the following criteria are to be selected for study- T. Cholesterol $\geq 200 \mathrm{mg} / \mathrm{dl}$, Triglycerides $\geq 150 \mathrm{mg} / \mathrm{dl}, \mathrm{HDL}<40$ $\mathrm{mg} / \mathrm{dl}, \mathrm{LDL} \geq 130 \mathrm{mg} / \mathrm{dl}$, total cholesterol/HDL ratio $\geq 4.5$

3. $\mathrm{BMI}>/=25 \mathrm{~kg} / \mathrm{m} 2$

B. Exclusion Criteria:

1. Age: Patient below 20 years and above 70 years.

2. Pregnant lady and Lactating lady ${ }^{5,9}$

3. Type 1 Diabetes Mellitus ${ }^{1,10}$ 
4. Chronic Renal failure

5. Carcinoma

6. Nephritic syndrome.

7. Bleeding disorders

8. Any serious trauma

9. Any Ano-rectal diseases ${ }^{3}$

10. Established familial history of Dyslipidemia.

11. $\mathrm{BMI}>40 \mathrm{~kg} / \mathrm{m} 2^{1,8,10}$

STUDY DESIGN: It was an Open Clinical Trial with pre-test and post-test conducted on 30 patients with elevated fasting lipid profile reports.
ASSESSMENT OF RESULTS: The assessment of the result of the patient was done based on the response of the trial drugs based on Fasting lipid profile, BMI, Circumference of Hip and Circumference of Waist before and after treatment on $30^{\text {th }}, 60^{\text {th }}$ and $90^{\text {th }}$ day respectively.

CRITERIA FOR WITHDRAWAL: The patient will be withdrawn from the therapy if any serious complication develops which requires urgent treatment during therapy.

\section{OBSERVATION AND RESULTS}

Table 3: Effects obtained before and after treatment shown in Investigations after 90 days.

\begin{tabular}{|c|c|c|c|c|c|c|c|c|c|c|}
\hline \multirow[t]{2}{*}{ Sl.no } & \multirow[t]{2}{*}{ Investigations } & \multicolumn{2}{|l|}{ Mean } & \multicolumn{2}{|l|}{ SD } & \multicolumn{2}{|l|}{ SEM } & \multirow[t]{2}{*}{ SED } & \multirow[t]{2}{*}{$\mathrm{T}$} & \multirow[t]{2}{*}{$\mathrm{P}$} \\
\hline & & BT & AT & BT & AT & BT & AT & & & \\
\hline 1 & Total Cholesterol & 271.23 & 179.5 & 68.82 & 50.3 & 12.5 & 9.2 & 11.97 & 7.65 & $<0.0001$ \\
\hline 2 & Serum Triglycerides & 322.1 & 150.6 & 117.38 & 70.24 & 21.43 & 12.82 & 16.55 & 10.36 & $<0.0001$ \\
\hline 3 & Serum HDL & 38.93 & 46.47 & 8.97 & 6.47 & 1.63 & 1.18 & 1.51 & 4.98 & $<0.0001$ \\
\hline 4 & Serum LDL & 131.36 & 106.2 & 34.63 & 23.10 & 6.32 & 4.21 & 4.68 & 6.34 & $<0.0001$ \\
\hline 5 & Serum VLDL & 58.85 & 41.9 & 19.35 & 20.9 & 3.53 & 3.8 & 2.83 & 5.97 & $<0.0001$ \\
\hline 8 & Circumference of hip & 102.18 & 98.6 & 10.65 & 9.79 & 1.94 & 1.78 & 0.79 & 4.43 & $=0.0001$ \\
\hline 9 & BMI & 29.66 & 26.27 & 4.70 & 3.48 & 0.85 & 0.63 & 0.47 & 7.08 & $<0.0001$ \\
\hline
\end{tabular}

\section{DISCUSSION}

From the statistical analysis, it is seen that the increased value of total cholesterol, triglycerides, LDL, VLDL and total Cholesterol: HDL ratio decreased and shows a significant result. The HDL value increased after the completion of the study period. There was a significant decrease in the circumference of the waist and hip. The BMI was also decreased after the completion of 90 days. The pharmacological properties of the ingredients of the trial formulation were mainly of katu, tikta, kashaya, ushna, tikshna, laghu and ruksha which are opposite to the properties of kapha and medas. The katutailaabhyanga followed by nadiswedan helps in kaphabilayana. The ingredients of medoharavidangadilauha are said to be effective against kaphavikaras. Thus, as a combination, they showed the significant result in the study.

\section{CONCLUSION}

Results obtained from the study reveals that the trial medicine is effective in correcting Dyslipidemia to a satisfactory level. Further, no adverse effect was observed in any patient during the trial. Thus, it can be concluded that Lekhanbasti along with Medoharavidangadilauha is effective in the management of dyslipidemia.

\section{REFERENCES}

1. Astanga Hridayam of Vagbhata, By Kaviraj Atridev Gupta, Edited by Vaidya Yadunandan Upadhayay, sutra sthana 19/7-8Chaukhamba Sanskrit Sansthan, 2018 reprinted Edition.

2. Ashtanga Hridayam of Vagbhata, By KavirajAtridev Gupta, Edited by Vaidya Yadunandan Upadhayay, sutra sthana 19/64Chaukhamba Sanskrit Sansthan, 2018 reprinted Edition.

3. Ashtanga Hridayam of Vagbhata, By Kaviraj Atridev Gupta, Edited by Vaidya Yadunandan Upadhayay, 
sutra sthana 19/4-5Chaukhamba Sanskrit Sansthan, 2018 reprinted Edition.

4. Bhaisajya Ratnavali "Vidyotini Hindi Vyakhya "Vimarsha" Parisistahita. By- Sri Ambikadutta Shastri, Ayurveda Acharya, Chaukhambha Sanskrit Sansthan, vol2 39/22-25

5. Brahmanand Tripathi Charak Samhita Sutrasthana, 21/9, Choukhamba Surbharati Prakashan, Varanasi.

6. CharakSamhita of KasinathShastri, Siddhisthana, vol2, Chaukhambha Sanskrit Sansthan.2/14

7. Susrutasamhita, Dr. Keval Krishna Thakral, Chaukhamba Orientalia, vol2, chikitsasthana, 38/82.

8. Ayurved Sara Sangraha of Baidyanathayurvedbhawan, lauha preparations.

9. Nayak, Annanda Prasad, A Comparative Study of Lekhan Therapy in the Management of Sthoulya (obesity) Int. J. Res. Ayurveda Pharm 2012;3(4):508514

10. Susruta Samhita, Dr. Keval Krishna Thakral, Chaukhamba Orientalia, vol2, chikitsasthana, 35/21.

\section{Source of Support: Nil \\ Conflict of Interest: None Declared}

How to cite this URL: Noor Sayeda Shabnam Ahmed Et Al: Clinical Evaluation Of The Efficacy Of Lekhanbasti And Medoharavidangadilauha In The Management Of Dyslipidemia. International Ayurvedic Medical Journal \{online\} 2021 \{cited July 2021\} Available from: http://www.iamj.in/posts/images/upload/1362_1365.pdf 